\title{
Fungicidal Property of Andrographis paniculata extract on Fungal Organisms from Citrullus colocynthis (L.) Schrad (Melon Seeds)
}

\author{
Chuku, E. C., Chika, B. and Nmom, F. W. \\ Department of Plant Science and Biotechnology, Rivers State University, Port Harcourt, Rivers State, Nigeria.
}

\begin{abstract}
Antifungal property of $A$. paniculata on fungal isolates from Citrullus colocynthis was investigated. Citrullus colocynthis were bought from traders in a major market in Abia State, Nigeria. The melon seeds were first cleaned and disinfested by keeping them in a freezer at $\mathbf{- 5 0 C}$ for 7 days to kill all hidden infestations. The disinfested seeds were dried in a Gallenkamp oven at $40^{\circ} \mathrm{C}$ for 4 hours before they were stored in plastic sterile containers with tight lids. Fresh plant of $A$. paniculata was collected from botanical garden of the Rivers State University and was identified in the botany department. The leaves of the plant were shade dried and blended into fine powder. Twenty grams $(20 \mathrm{~g})$ of the powdered leaves was extracted using methanol and ethanol. The filtrate was evaporated and the resulting crude extract was used for antifungal sensitivity test. Fungi associated with rotted $C$. colocynthis were identified using standard microbiological methods. The antifungal activity of the extracts was carried out using the well in agar diffusion method. In this method, 48 hours old fungal isolate was inoculated on dried Sabouraud Dextrose Agar plates in duplicates. five wells were bored using sterile $6 \mathrm{~mm}$ cork borer on the dried seeded plates before $0.2 \mathrm{ml}$ of the different concentrations of $100,50,25$, and $12.5 \mathrm{mg} / \mathrm{ml}$ of the methanol extracts were transferred into the wells using sterile pipettes. Aspergillus flavus, Rhizopus arrhizus, Aspergillus niger, Rhizopus sp and Mucor sp were identified from the melon seeds. The zone diameters of methanolic extract of $A$. paniculata on Rhizopus arrhizus, A. niger, A. flavus, Rhizopus sp and Mucor sp were $11.50 \pm 0.71,19.50 \pm 0.71,34.50 \pm 0.71$, $15.00 \pm 0.00$ and $17.00 \pm 0.00 \mathrm{~mm}$, respectively. The zone diameters of ethanolic extract of $A$. paniculata on Rhizopus arrhizus, A. niger, A. flavus, Rhizopus sp and Mucor sp were $0.00 \pm 0.00,16.50 \pm 0.71,34.50 \pm 0.71$, $20.50 \pm 0.71$ and $0.00 \pm 0.00 \mathrm{~mm}$, respectively. There were significant differences $(P \leq 0.05)$ in the antifungal activity of the extract across the fungal isolates. The antifungal activity of the leave extracts showed that the ethanolic extract and the methanolic extract were very active on the fungal isolates and the antifungal activities of the extract was greatly influenced by the concentration of the extract, with higher concentrations of extract having high zone diameter.
\end{abstract}

Keyword:- antifungal, Andrographis paniculata, fungi, local gin ("kai kai")

\section{INTRODUCTION}

Chemical control of most fungal and insect diseases of plants may be available and could extensively reduce the impact of plant diseases, but field application of synthetic fungicides may not always be desirable. Infestation of food and food products by microorganism cause spoilage of food materials. Fungi is one of the microorganisms that deteriorates food and such deterioration could be beneficial or lead to eventual spoilage as it could affect the quality of the food [1]. According to Hussaini [2], fungi are plant pathogens that are widely distributed in different environments and are the main cause of deterioration of foods and feed stuffs. The deterioration or spoilage of food could also lead to the loss in nutritional value, organoleptic taste, colour change and affect the safety of the food [3].

Andrographis paniculata (Burm.f.) which is otherwise called the "King of Bitters" is a yearly herbaceous plant local to India and Sri Lanka. It is broadly developed in Southern and South eastern Asia, where it has been generally used to treat contaminations and a few ailments. It is local to peninsular and is additionally conveyed in West Indies and Christmas Island. It is developed as a result of its notable therapeutic worth and it develops well in most soil types, in this manner it is generally dispersed [4]. Reports of the antifungal activity of A. paniculata is well documented but there is dearth of information in respect to the chemical nature of the antifungal compounds inherent in the plant. The compound 3-O- $\beta$-D-glucosyl-14deoxyandrographolide, 14-deoxy andrographolide and 14deoxy-11, 12-didehydro andrographolide has been reported as an antifungal compound inherent in the plant [5]

Plant extricates, fundamental oils, gums, gums have been appeared to apply natural movement against plant contagious pathogens in vitro and in vivo and can be utilized as bio-fungicidal items [6, 7]. These items are commonly thought to be increasingly worthy and less risky for the environments and could be utilized as elective solutions for treatment of plant diseases [8]. Furthermore, these compounds are natural in origin, have minimum adverse effects on the physiological processes of plants and are easily convertible into common eco-friendly organic materials [9]. Due to the improper use and hazards posed by chemical fungi agents, there is a growing concern towards the use of fungicides that are environmentally friendly and would not pose any public health challenge to humans who consume the products. The aim of this study is 
to investigate the antifungal property of methanol and ethanol extracts of $A$. paniculata on fungal isolates.

\section{MATERIALS AND METHOD}

\section{$>$ Collection of Materials}

Fresh leaves of $A$. paniculata were collected from the botanical garden of the Rivers State University. The plant was properly identified by a taxonomist in the department of plant science and biotechnology, Rivers State University. The leaves were air dried in the laboratory until they all were crispy. Dried leaves were later ground into fine powder and stored in clean container for further use.

Melon seeds, Colocynthis citrullus (spoilt and good) were bought from traders in a major market in Abia State, Nigeria. The melon seeds were first cleaned and disinfested by keeping them in a freezer at $-5^{0} \mathrm{C}$ for 7 days to kill all hidden infestations. The disinfested seeds were dried in a Gallenkamp oven (Model 250) at $40^{\circ} \mathrm{C}$ for 4 hours as described by Jambere et al. [10] before they were stored in plastic sterile containers (disinfested by swabbing with 90 $\%$ alcohol) with tight lids.

\section{Extraction of Andrographis paniculata}

Two extracting solvents were used in extraction. The powdered form of $A$. paniculata was extracted as described by Robinson et al. [1]. In this method, $20 \mathrm{~g}$ of the powdered leaves was immersed in two separate $250 \mathrm{ml}$ beaker containing $200 \mathrm{ml}$ of ethanol and methanol, respectively. The set up was homogenized by swirling and was allowed to stand for forty-eight hours. After extraction, the leave extracts were filtered with sterile filter paper (Whatman no1 filter paper) into sterile $250 \mathrm{ml}$ beakers. The filtrate was evaporated to dryness in the hot air oven at $45^{\circ} \mathrm{C}$. The resulting oily residue was weighed and stored in sterile containers which were preserved in the refrigerator for further use. The percentage yield of the extract was calculated using the formula below;

Yield $(\%)=\frac{\text { weight of Extract recovered }}{\text { weight of dry powder }} \times 100$

\section{$>$ Isolation and Identification of Fungi}

Ten grams of spoilt melon seeds were transferred into $90 \mathrm{ml}$ of sterile normal saline in a $150 \mathrm{ml}$ conical flask. This served as the stock (solution). With the aid of sterile pipettes, $1 \mathrm{ml}$ of the mixture was transferred from the stock into test tubes containing sterile $9 \mathrm{ml}$ diluent (normal saline) using the ten-fold serial dilution [11]. Aliquot $(0.1 \mathrm{~m})$ of the stock dilution $\left(10^{-1}\right)$ and the $10^{-2}$ dilution were inoculated on well dried $200 \mu \mathrm{g}$ tetracycline supplemented Sabouraud Dextrose Agar (SDA) plates in duplicates. Inoculated plates were incubated at $22^{\circ} \mathrm{C}$ for 5 days. Fungal colonies which ensued after incubation were isolated by inoculating fungal spores on fresh SDA plates and were incubated at $222^{\circ} \mathrm{C}$ for 3 days. Identification of fungal isolates was carried out as described by Douglas by previous studies [12, 13]. The identities of the fungal isolates were confirmed by comparing with those in the book of descriptions of medical fungi by Sarah et al. [14].

\section{Preparation of Extracts Concentrations for antifungal Assay}

Stock solution of ethanolic and methanolic extract was prepared by dissolving $100 \mathrm{mg}$ of the oily residue in $1 \mathrm{ml}$ of Dimethyl sulfoxide (DMSO) which gave rise to $100 \mathrm{mg} / \mathrm{ml}$ stock of the extract. Further two-fold serial dilution was carried out by diluting $1 \mathrm{ml}$ of the stock solution into $1 \mathrm{ml}$ of sterile distilled water to achieve the concentrations of $50 \mathrm{mg} / \mathrm{ml}, 25 \mathrm{mg} / \mathrm{ml}$ and $12.5 \mathrm{mg} / \mathrm{ml} \mathrm{[1]}$.

\section{Antifungal Activity of Extracts}

The antifungal activity of the extracts was carried out using the agar well diffusion method. In this method, 48 hours old fungal isolates which were grown on $9 \mathrm{ml}$ sterile Sabouraud Dextrose broth was inoculated on well dried and labelled accordingly. Sabouraud Dextrose Agar (SDA) plates in duplicates. The plates were allowed to dry for 3 minutes before five wells were bored using sterile $6 \mathrm{~mm}$ cork borer. $0.2 \mathrm{ml}$ of different concentrations $(100,50,25$, and $12.5 \mathrm{mg} / \mathrm{ml}$ ) of the extracts were transferred into the bored wells using sterile pipettes. The positive control was $10 \mathrm{mg} / \mathrm{ml}$ miconazole antifungal agent while the negative control was $10 \%$ DMSO. The plates were incubated at $25^{\circ} \mathrm{C}$ for forty-eight hours. Zone diameter were measured using graduated rule and the result was recorded. Sterility of the extract was confirmed by streaking the different extracts on nutrient and Sabouraud Dextrose Agar plates which were later incubated for forty-eight hours. The absence of growth after incubation means that the extracts were sterile. 


\section{RESULT AND DISCUSSION}

Five fungal isolates were identified from the melon seeds and they include; Aspergillus flavus, Rhizopus arrhizus, Aspergillus niger, Rhizopus sp and Mucor sp. The morphology and microscopy of these fungal isolates (Table 1) matched with those presented in the description of medical fungi by Sarah et al. [14].

\begin{tabular}{|c|c|c|c|}
\hline $\begin{array}{c}\text { Isolate } \\
\text { code }\end{array}$ & Macroscopy & Microscopy & Probable identity \\
\hline A & $\begin{array}{c}\text { Yellow-green spores, white } \\
\text { periphery, brown reverse }\end{array}$ & $\begin{array}{c}\text { Conidia is globose and rough walled head, with } \\
\text { hyaline stipes of conidiophore }\end{array}$ & A. flavus \\
\hline B & $\begin{array}{c}\text { White cottony, brownish grey to } \\
\text { black-grey coloration, brown } \\
\text { reverse }\end{array}$ & $\begin{array}{c}\text { Smooth walled and non-septate branched } \\
\text { sporangiophores, presence of rhizoids }\end{array}$ & A. niger \\
\hline C & $\begin{array}{c}\text { White periphery, densed black } \\
\text { spores, dark brown reverse }\end{array}$ & $\begin{array}{c}\text { Hyaline conidiophore phialides borne on vesicles, } \\
\text { chains of conidia with septate hyphae }\end{array}$ & Rhizopus sp \\
\hline D & White cottony mycelium & $\begin{array}{c}\text { Non-septate hyphae, large globose with many } \\
\text { sporangia on sporangiophore }\end{array}$ & Mucor sp \\
\hline E & $\begin{array}{c}\text { White loosed cotton wool-like } \\
\text { aerial mycelium, white reverse }\end{array}$ & $\begin{array}{c}\text { Non-septate mycelia bearing sporangiophore } \\
\text { scattered all over the mycellium }\end{array}$ & \\
\hline
\end{tabular}

Table 1:- Description of fungal Isolates

Percentage Yield of the Extract

The result of the percentage $(\%)$ yield of the extract showed that methanol solvent yielded higher percentage and grams of the oily extract. The percentage yield was $11.5 \%$ and the weight of the extract was $2.3 \mathrm{~g}$, while the percentage yield of ethanol was 9.0 and the weight of the oily extract was $1.8 \mathrm{~g}$ (Table 2).

\section{Antifungal Sensitivity}

The result of the antifungal sensitivity of the extracts of methanol and ethanol are presented in Table 3 and Table 4, respectively. Notable zones of inhibition were recorded for both extracts even though some of the isolates were not sensitive to the extracts. The zone diameters of some of the fungal isolates are presented in Plate 1 and Plate 2.

\begin{tabular}{|c|c|c|c|c|}
\hline Solvent of extraction & Colour of Extract & $\begin{array}{c}\text { Weight of sample } \\
\text { used }(\mathrm{g})\end{array}$ & Weight of extract (g) & $\begin{array}{c}\text { Percentage }(\%) \text { yield of } \\
\text { extract }\end{array}$ \\
\hline Methanol & Leaf Green & 20 & 2.3 & 11.5 \\
\hline Ethanol & Dark Brown & 20 & 1.8 & 9.0 \\
\hline
\end{tabular}

Table 2:- Percentage Yield of the Crude Extract of A. paniculata

\begin{tabular}{|c|c|c|c|c|c|}
\hline Isolate & C & $100 \mathrm{mg} / \mathrm{ml}$ & $50 \mathrm{mg} / \mathrm{ml}$ & $25 \mathrm{mg} / \mathrm{ml}$ & $12.5 \mathrm{mg} / \mathrm{ml}$ \\
\hline & \multicolumn{4}{|c|}{ Zone Diameter $(\mathrm{mm})$} \\
\hline Rhizopus arrhizus & $0.00 \pm 0.00^{\mathrm{a}}$ & $11.50 \pm 0.71^{\mathrm{a}}$ & $0.00 \pm 0.00^{\mathrm{a}}$ & $0.00 \pm 0.00^{\mathrm{a}}$ & $0.00 \pm 0.00^{\mathrm{a}}$ \\
\hline A. niger $^{\mathrm{a}}$ & $28.50 \pm 0.71^{\mathrm{b}}$ & $19.50 \pm 0.71^{\mathrm{b}}$ & $10.50 \pm 0.71^{\mathrm{b}}$ & $0.00 \pm 0.00^{\mathrm{a}}$ & $0.00 \pm 0.00^{\mathrm{a}}$ \\
\hline A. flavus & $27.50 \pm 0.71^{\mathrm{b}}$ & $34.50 \pm 0.71^{\mathrm{c}}$ & $30.50 \pm 0.71^{\mathrm{c}}$ & $21.00 \pm 1.41^{\mathrm{b}}$ & $.00 \pm 0.00^{\mathrm{a}}$ \\
\hline Rhizopus sp & $0.00 \pm 0.00^{\mathrm{a}}$ & $15.00 \pm 0.00^{\mathrm{a}}$ & $10.50 \pm 0.71^{\mathrm{b}}$ & $0.00 \pm 0.00^{\mathrm{a}}$ & $0.00 \pm 0.00^{\mathrm{a}}$ \\
\hline Mucor sp & $0.00 \pm 0.00^{\mathrm{a}}$ & $17.00 \pm 0.00^{\mathrm{b}}$ & $0.00 \pm 0.00^{\mathrm{a}}$ & $0.00 \pm 0.00^{\mathrm{a}}$ & $0.00 \pm 0.00^{\mathrm{a}}$ \\
\hline
\end{tabular}

Table 3:- Antifungal activity of Methanolic extract of Andrographis paniculata

*Means with similar superscript have no significant difference at $\mathbf{P} \leq \mathbf{0 . 0 5}$

Key: C: control (10mg/ml miconazole antifungal) 
ISSN No:-2456-2165

\begin{tabular}{|c|c|c|c|c|c|}
\hline Isolate & $\mathrm{c}$ & $100 \mathrm{mg} / \mathrm{ml}$ & $50 \mathrm{mg} / \mathrm{ml}$ & $25 \mathrm{mg} / \mathrm{ml}$ & $12.5 \mathrm{mg} / \mathrm{ml}$ \\
\hline & \multicolumn{5}{|c|}{ Zone Diameter $(\mathrm{mm})$} \\
\hline R. arrhizus & $0.00 \pm 0.00^{\mathrm{a}}$ & $0.00 \pm 0.00^{\mathrm{a}}$ & $0.00 \pm 0.00^{\mathrm{a}}$ & $0.00 \pm 0.00^{\mathrm{a}}$ & $0.00 \pm 0.00^{\mathrm{a}}$ \\
\hline A. niger & $18.50 \pm 0.71^{\mathrm{b}}$ & $16.50 \pm 0.71^{\mathrm{b}}$ & $14.50 \pm 0.71^{\mathrm{b}}$ & $11.50 \pm 0.71^{\mathrm{b}}$ & $0.00 \pm 0.00^{\mathrm{a}}$ \\
\hline A. flavus & $35.00 \pm 0.00^{\mathrm{d}}$ & $34.50 \pm 0.71^{\mathrm{d}}$ & $22.50 \pm 0.71^{\mathrm{c}}$ & $20.50 \pm 0.71^{\mathrm{c}}$ & $0.00 \pm 0.00^{\mathrm{a}}$ \\
\hline Rhizopus $\mathrm{sp}$ & $24.50 \pm 0.71^{\mathrm{c}}$ & $20.50 \pm 0.71^{\mathrm{c}}$ & $0.00 \pm 0.00^{\mathrm{a}}$ & $0.00 \pm 0.00^{\mathrm{a}}$ & $0.00 \pm 0.00^{\mathrm{a}}$ \\
\hline Mucor $\mathrm{sp}$ & $19.50 \pm 0.71^{\mathrm{b}}$ & $0.00 \pm 0.00^{\mathrm{a}}$ & $0.00 \pm 0.00^{\mathrm{a}}$ & $0.00 \pm 0.00^{\mathrm{a}}$ & $0.00 \pm 0.00^{\mathrm{a}}$ \\
\hline
\end{tabular}

Table 4:- Antifungal activity of Ethanolic extract of Andrographis paniculata extract

\section{*Means with similar superscript have no significant difference at $\mathbf{P} \leq \mathbf{0 . 0 5}$ Key: C: control (10mg/ml miconazole antifungal)}

\section{Antifungal Susceptibility}

Most fungi are responsible for different form of fungal infections; respiratory, allergenic and other mycoses. The antifungal susceptibility of the ethanolic and methanolic extract of A. paniculata on fungi isolated from melon seeds showed that the leave extracts hold promise in the treatment of fungi infections especially those in this current study. This was buttressed from the fact that fungal spores were highly inhibited at different concentrations of the extracts. The antifungal activities of the ethanol and methanol extracts of A. paniculata was dependent on the amount of concentration. Higher concentrations had more antifungal actions.

\section{- Methanol Extract}

The antifungal activity of methanolic extract of $A$. paniculata showed that Rhizopus arrhizus which was resistant to $10 \mathrm{mg} / \mathrm{ml}$ of miconazole was susceptible to the extract with notable zone diameter of $11.50 \pm 0.71 \mathrm{~mm}$ at the $100 \mathrm{mg} / \mathrm{ml}$ concentration. This concentration was the minimal inhibitory concentration (MIC) of methanolic extract of A. paniculata on Rhizopus arrhizus. Also, the zone diameter of the methanolic extract on A. niger were very sensitive at $100 \mathrm{mg} / \mathrm{ml}$ and $50 \mathrm{mg} / \mathrm{ml}$. The antifungal effects of miconazole on $A$. niger showed higher zone diameter as compared to the zone diameter of the methanolic extract. The MIC of the extract on A. niger was $50 \mathrm{mg} / \mathrm{ml}$ (Table 3). The effect of the extract on A. flavus was more effective. This is because the MIC on A. flavus was $25 \mathrm{mg} / \mathrm{ml}$ where as in the other isolates, the MIC were in $100 \mathrm{mg} / \mathrm{ml}$ and $50 \mathrm{mg} / \mathrm{ml}$ (Table 3). More so, the antifungal activity of the extract on A. flavus was higher than that of the miconazole which is a known antifungal agent. Rhizopus sp and Mucor sp which were resistant to miconazole were very susceptible to the methanolic extract of A. paniculata. Two-way ANOVA showed some level of significance in the effect of miconazole on the different fungi at $\mathrm{P} \leq 0.05$. At $100 \mathrm{mg} / \mathrm{ml}$ concentration, there was a significant difference in the effect of the extract on the different fungal isolates. The effect of the extract at $100 \mathrm{mg} / \mathrm{ml}$ on Rhizopus arrhizus and Rhizopus sp which were the least zone diameter were significantly different from the effects on Mucor, A. niger and A. flavus. Similarly, there was a slight significant difference in the effect of the extract at $50 \mathrm{mg} / \mathrm{ml}$ concentration on the different fungal isolates.

\section{- Ethanol Extract}

The ethanolic extract of $A$. paniculata on $R$. arrhizus and Mucor sp showed no antifungal activity. Furthermore, the antifungal activity of the ethanol extract was very effective against the isolates of $A$. niger and A. flavus with higher zones of inhibition observed on A. flavus. The MIC of the extract on these two fungal isolates was at the $25 \mathrm{mg} / \mathrm{ml}$ concentration (Table 4 ). The antifungal activity of the extract on Rhizopus sp was inhibited at the $100 \mathrm{mg} / \mathrm{ml}$ concentration alone. Two-way ANOVA showed significant difference between the zone diameter of the fungal isolates at $100 \mathrm{mg} / \mathrm{ml}$ concentration. $R$. arrhizus and Mucor sp were completely resistant to the extract. More so, there was a significant difference in between the zone diameter of the different fungal isolates at the $50 \mathrm{mg} / \mathrm{ml}$ and $25 \mathrm{mg} / \mathrm{ml}$ concentrations (Table 4).

Generally, a comparison was drawn between the effects of the ethanolic and the methanolic extracts on the different fungal isolates. The ethanolic extract had no effect on $R$. arrhizus while the methanolic extract was very sensitive. At $100 \mathrm{mg} / \mathrm{ml}$ concentration, the effect of the ethanolic extract was less than the effect of the methanolic extract on A. niger. Also, the zone diameter at the $50 \mathrm{mg} / \mathrm{ml}$ concentration of the ethanolic extract on A. niger was higher than the zone diameter of the methanolic extract. Furthermore, at the $25 \mathrm{mg} / \mathrm{ml}$ concentration, spores of $A$. niger were inhibited by the ethanolic extract of $A$. paniculata while the methanolic extract had no antifungal effect at this concentration. Thus, the ethanolic extract was more sensitive with more antifungal activity on $A$. niger than the methanolic extract. The zone diameter of the ethanolic and methanolic extract on A. flavus were the same at $100 \mathrm{mg} / \mathrm{ml}$ concentration, while at $50 \mathrm{mg} / \mathrm{ml}$ concentration, the methanolic extracts had higher zone diameter on $A$. flavus than the zone diameter of the ethanolic extract. Also, at the $25 \mathrm{mg} / \mathrm{ml}$ concentration, the methanolic extract was more active than the ethanolic extract on A. flavus. The effect of the methanolic extract on Rhizopus sp was less effective as compared to the effect of the ethanolic extract. The methanolic extract of $A$. 
paniculata was sensitive with higher antifungal activity on Mucor sp while the ethanolic extract had no antifungal activity on Mucor sp. The antifungal activities of $A$. paniculata on Candida albicans and Aspergillus flavus has been demonstrated to be very effective by Radha et al. [15]. Though the level of activity of petroleum ether, chloroform, acetone and methanol extract of $A$. paticulata on A. flavus at $100 \%$ concentration which were $0.0 \pm 0.0,15.67 \pm 1.20$, $9.33 \pm 0.88$ and $19.33 \pm 0.88 \mathrm{~mm}$, respectively were less than the zone diameter of ethanol and methanol extract in this current study. The antifungal activity of the extracts was affected by the level of concentration as the degree of effectiveness decreased with decreased concentration. This statement agreed with Robinson et al. [1] and Radha et al. [15] in which the antifungal activity was highest at $100 \%$ concentration as compared to lower concentration. A. paniculata is known to be used for herbal medicine and it is usually referred to as 'king of bitters' [16]. Similar results of the ethanolic and methanolic extract of A. paniculata on fungal isolates of melon seeds has been demonstrated in a previous study [1]. The use of the plant in treatment of diseases is not new. According to Alpha [17], the plant is used for treatment of chronic and infectious diseases in Asia as well as treatment of upper respiratory tract infections and gastrointestinal infections. In a study of the antifungal activity of $A$. paniculata by Eugene and Girija [5], it was gathered that amongst the three extracting solvents used, only the methanolic extract had antifungal activity of $33.0 \pm 1.5 \mathrm{~mm}$ on $F$. solani. Thus, there study established that $A$. paniculata exhibits antifungal activity which agreed with the findings in this current study. The presence of the compound andrographolide in the methanolic extract was said to be responsible for the antifungal activity [5]. Furthermore, Abubakar et al. [18] in a study of the Antifungal activity of Andrographis paniculata extracts and active principles against skin pathogenic fungal strains in vitro, reported that the extracts had good inhibitory effects against Trichophyton mentagrophytes, Trichophyton rubrum, Microsporum canis, Candida albicans, Candida krusei, Candida tropicalis and Aspergillus niger. The antifungal activities of A. paniculata has been attributed to the presence of different secondary metabolites and the concentrations of these secondary metabolites in significant quantities are said to influence the antimicrobial activities of $A$. paniculata $[18,19]$. Although other study reported that the antimicrobial activity of $A$. paniculata is due to the synergic effects of the compound (andrographolide) isolated from the plant which had strong antimicrobial activity than the plant extracts [20, 21]. Plant extracts are being exploited for their antimicrobial activities in treating infections caused by bacteria, viruses, fungi and other health related diseases [22].

\section{CONCLUSION}

This study has demonstrated that the antifungal activity of ethanolic extract and the methanolic extract of $A$. paniculata were more active than the synthetic antifungal drug. Thus, it could be used as an antifungal agent since it had great antifungal activity against the fungal isolates from melon seeds.

\section{REFERENCES}

[1]. Robinson, V. K., Nnamdi, A. U. and Korobe, B. P. (2020). Antifungal activity of Local Gin (Kai Kai) extract of Andrographis paniculata on fungal Isolates. International Journal of Research and Innovation in Applied Science; volume V, Issue VI, 2020.

[2]. Hussaini, A. M. (2013). Mycotoxin and Food Safety in Developing Countries. http://dx.doi.org/10.5772/3414.

[3]. Hocking, A. D., Pitt, J. I., Samson, R. A. and Thrane U. (2006). (eds), Advances in Food Mycology (Springer, New York, 2006).

[4]. Agbonlahor O, Joyce E. F, Osayemwenre E, Vincent I, Abiodun F, Peter L. (2014). Harnessing the medicinal properties of Andrographis paniculata for diseases and beyond: a review of its phytochemistry and pharmacology. Asian Pacific Journal of Tropical Disease, 4(3): 213-222.

[5]. Eugene S. J. N, Girija G. A.N. L. (2015). Antifungal activity of the extract of Andrographis paniculata and andrographolide. Journal of Pharmacognosy and Phytochemistry 2015; 4(2): 08-10

[6]. Fawzi, E. M., Khalil, A. A. and Afifi, A. F. (2009). Antifungal effect of some plant extracts on Alternaria alternata and Fusarium oxysporum. African Journal of Biotechnology, 8(11): 2590-2597.

[7]. Romanazzi, G., Lichter, A., Gabler, F. M. and Smilanick, J. L. (2012). Recent advances on the use of natural and safe alternatives to conventional methods to control postharvest gray mold of table grapes. Postharvest Biology and Technology, 63:141-147.

[8]. Chuang, P. H., Lee, C. W., Chou, J. Y., Murugan, M., Shieh, B. J. and Chen, H. M. (2007). Antifungal activity of crude extracts and essential oil of Moringa oleifera Lam. Bioresource Technology, 98:232-236.

[9]. Gnanamanickam, S. S. (2002). Biological control of crop diseases. Marcel Dekker Inc., New York, USA, p. 468.

[10]. Jambere, B., Obeng-Ofori, D. and Hassanali, A. (1995). Products derived from the leaves of Ocimum kilmandsharicum as post harvest grain protestant against the infection of three major stored insect product pests. Bulletin of Entomological Research, 85, 351-367.

[11]. Amadi E.N, Kiin-Kabari D.B, Kpormon, L.B, Robinson V.K.K. Microbial flora and nutritional composition of adult Palm - Wine Beetle (Rhynchophorus phoenicus). International journal of Current Microbiology and Applied Science. 2014; 3(11) 189-192. 
[12]. Douglas, S. I. and Robinson, V. K. (2019). Indoor Microbiological Air Quality in Some Wards of a Tertiary Health Institution in Port Harcourt, Nigeria. Journal of Pharmacy and Biological Sciences; 14: 4450.

[13]. Douglas, S. I. and Robinson, V. K. (2018). Fungal Pollution of Indoor Air of Some Health Facilities in Rivers State. International Journal of Tropical Disease \& Health; 32(2): 1-7.

[14]. Sarah, K., Catriona, H., Helen, A. And David, E. (2016). Descriptions of Medical Fungi (3rd edn). ISBN:9780646951294.

[15]. Radha, R., Sermakkani, M. and Thangapandian, V. (2011). Evaluation of phytochemical and antimicrobial activity of Andrographis paniculata nees (Acanthaceae) aerial parts. International Journal of Pharmacy \& Life Sciences; 2(2): 562-567.

[16]. Jarukamjorn, K. and Nemoto, N (2008). Pharmacological aspects of Andrographis paniculata on health and its major diterpenoid constituent andrographolide. Journal of Health Science; 54 (4): 370-381.

[17]. Alpha Omega Labs. (2008). Andrographis In-depth Review. Alpha Omega Laboratories, Guayaquil, Ecuador. Retrieved October 15, 2019, from http://www.altcancer.com/andcan.htm.

[18]. Abubakar, S., Qamar, U. A, Jalifah, L.., Othman, A. S., Muhammad, N. O., Abdulrashid, U. and Bashar B. (2012). Antifungal activity of Andrographis paniculata extracts and active principles against skin pathogenic fungal strains in vitro. Pharmaceutical Biology; 50(7): 850-856.

[19]. Athikomkulchai S, Prawat H, Thasana N, Ruangrungsi N, Ruchirawat S. (2006). COX-1, COX2 inhibitors and antifungal agents from Croton hutchinsonianus. Chem Pharm Bull, 54, 262-264.

[20]. Mbaveng, A.T., Kuete, K., Nguemeving, J.R., Beng, V.P., Nkengfack, A.E., Meyer, J.M., Lall N. and Krohn, K. (2008). Antimicrobial activity of the extracts and compounds obtained from Vismia guineensis (Guttiferae). Asian Journal of Traditional Medicine, 3, 211-223.

[21]. Sopa, K., Supinya, T. and Sanan, S. (2008). Antimicrobial activity of the ethanol extract and compounds from the rhizomes of Kaempferia parvilora. Songklanakarin Journal of Science \& Technology; 30, 463-466.

[22]. Kosalec, I., Pepeljnjak, S. and Kustrak, D. (2005). Antifungal activity of luid extract and essential oil from anise fruits (Pimpinella anisum L., Apiaceae). Acta Pharmacology; 55, 377-385. 